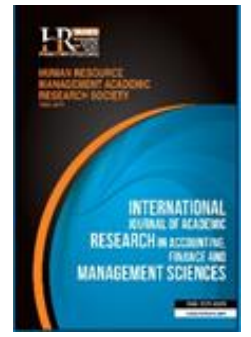

International Journal of Academic Research in Accounting, Finance and Management Sciences

Vol. 10, No.3, July 2020, pp. 28-37

E-ISSN: 2225-8329, P-ISSN: 2308-0337

(C) 2020 HRMARS

www.hrmars.com

To cite this article: Malla, N. Asianto, A. (2020). The Determinant of Mining Sector Stock Price Index at Indonesia Stock Exchange, International Journal of Academic Research in Accounting, Finance and Management Sciences. 10(3), 28-37.

\title{
The Determinant of Mining Sector Stock Price Index at Indonesia Stock Exchange
}

\author{
Nitha Malla ${ }^{1}$, Abitur Asianto $^{2}$ \\ 1,2Department of Business Management, Mercu Buana University, Jakarta, Indonesia, \\ ${ }^{1}$ E-mail: nitha.malla@gmail.com, ${ }^{2}$ E-mail: abitur.asianto@mercubuana.ac.id
}

\begin{abstract}
This research has purposed to analyze these determinants from mining sector stock index at Indonesia Stock Exchange. This research used the Vector Error Correction Model and monthly data on mining sector stock index as dependent variable and the independent variables were inflation, BI interest rate, Gross Domestic Product, exchange rate, demand and supply of coal, coal prices and world crude oil prices from January 2014 to August 2019. These empirical results shows that shocks variable on inflation, coal supply \& demand, coal prices and crude oil prices will be responded positively by mining sector stock index in the long term while shocks variable on GDP, BI interest rates and exchange rates will be responded negatively by mining sector stock index in long-term. It means all variables are determinant of mining sector stock price index at IDX. Coal demand variable would contribute dominantly to the fluctuation of mining sector stock index. The increased in coal demand will be followed by increased in mining sector stock index.

Key words

Mining Sector Stock Index, determinants, Indonesia Stock Exchange, Vector Error Correction Model

\begin{tabular}{|c|c|c|}
\hline Received: & 05 Jul 2020 & (C) The Authors 2020 \\
\hline Revised: & 03 Aug 2020 & Published by Human Resource Management Academic Research Society (www.hrmars.com) \\
\hline $\begin{array}{l}\text { Accepted: } \\
\text { hed Online: }\end{array}$ & $\begin{array}{l}01 \text { Sep } 2020 \\
14 \text { Sep } 2020\end{array}$ & $\begin{array}{l}\text { This article is published under the Creative Commons Attribution (CC BY } 4.0 \text { ) license. Anyone may } \\
\text { reproduce, distribute, translate and create derivative works of this article (for both commercial and } \\
\text { non-commercial purposes), subject to full attribution to the original publication and authors. The full } \\
\text { terms of this license may be seen at: http://creativecommons.org/licences/by/4.0/legalcode }\end{array}$ \\
\hline
\end{tabular}
\end{abstract}

\section{Introduction}

A country's economic growth could be measured from its macro-economic conditions and how it responds to shocks that arise in its country's macroeconomics. According to Inglis (2014), the resilience of economy towards macro-economic shocks could be measured by the resilience of capital market. The development/growth of country's economy cannot be separated from investment activities because it has a strategic role. Without investment activity, economic growth will tend to stagnate. One of the most popular investment instruments is stocks. Capital market can be an investment place to obtain dividend yields and capital gains as well as obtained ownership rights over the company so that referring to the statement of Tandelilin (2010) which states that the main reason for an investor to invest or buy shares is to earned profit or return. When the stock index decreased, investors could invest in buying these shares to gained profit when the stock increased in these following year, as well as experienced by mining sector stock index at IDX.

The mining sector is one of sectors that support the economic development of a country because it acts as provider of energy resources such as coal, oil and gas, metals and minerals as well as rocks which are indispensable and necessary for a country's economic growth. In Indonesia, the mining sector has become an increasingly strategic sector because it plays an important role in Indonesia's development, such as an addition to state revenue. Mining sector is investment option. Investors who want to invest in 
mining sector need to pay for attention to its movement because the movement of stock index is an important factor in choosing stocks because stock index used as a source of information to determine current stock market conditions which in better or worse from its prior period.

Interesting phenomenon occurred in 2012-2015, when most of the industrial sector stock index values had experienced an increase except for mining sector stock index value which continued to decline. A significant decreased occurred during 2014-2015, then experienced a gradual increased in 2016-2018. So it could be said that mining sector was quite reliable sector, because even though it experienced a fairly large declined in 2015, but it still could survive until now. The increased in value of mining sector stock index could be a consideration for investors to invest in mining sector. This capital market indicator could be fluctuating in line with changes in macroeconomic indicators in Indonesia. According to Bodie (2014) macro-economic factors that could influenced the stock price index were inflation, interest rate policy, exchange rates, gross domestic product, social and political conditions. Factors that influenced this fluctuation from mining sector stock index were very important information for investors to predict the changes that will occur in the mining sector stock index to make an investment decisions.

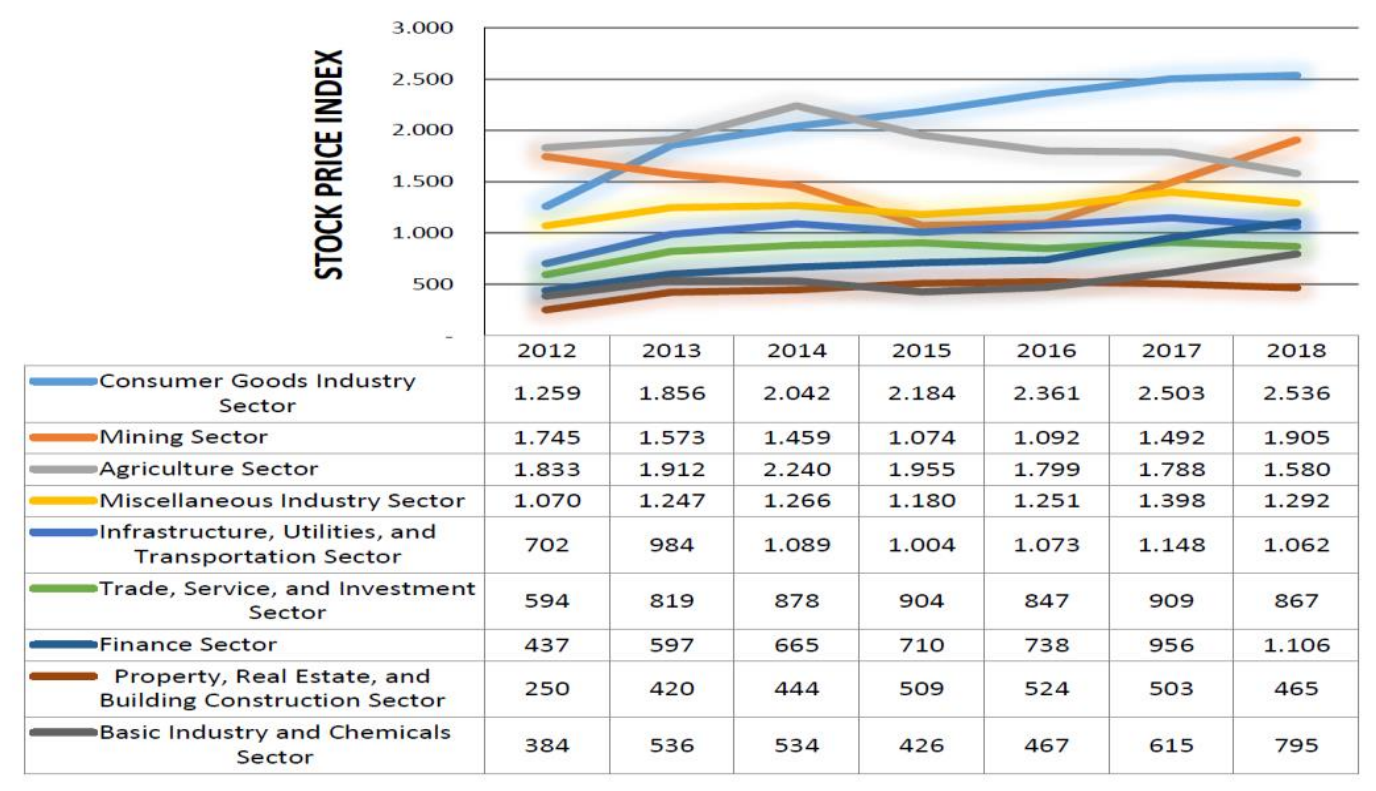

Figure 1. The Movement of the Sectoral Stock Index at IDX

Several previous research regarding those impact towards inflation, BI interest rates, GDP, exchange rates, coal prices and crude oil prices on stock prices that will affect these sectoral stock index movements as described as follows: Wahyudi et al. (2017) shows that inflation had negative influence over stock price index. Meanwhile, Amadasu's research (2012) shows that inflation had positive influence on mining sector stock price index. Anisa \& Ari's (2018) research results shows that inflation had no influence on mining sector stock price index.

The results from research by Muhammadi (2010), Adarmola \& Anthony (2011) shows that interest rates had positive influence towards stock price index while the results from research whom conducted by Prowanta (2017), Amadasu (2012), Wahyudi et al. (2017) shows that interest rates had negative impact towards mining sector stock prices. The research results of Prowanta (2017) shows that GDP had positive impact towards stock price index, while research results from Adarmola \& Anthony (2011) was indicated that GDP had negative influence against stock prices. Muhammadi's research (2010) shows that GDP had no influence towards sectoral stock index in Indonesia except for financial sector.

These research results from Adarmola \& Anthony (2011), Amadasu (2012), Prowanta (2017), Wahyudi et al. (2017), Adesanmi \& Dadang (2017) described that the exchange rate had positive influence over index share prices while the research results from Fardiansyah et al. (2018) shows that exchange rate had negative influence towards stock price index. The results from Zurdona's research (2018) shows that coal prices had positive influence towards mining index either in short and long term while the results of research by Fardiansyah et al (2018) tells that coal prices had positive impact to mining sector index in 
short term and negative influence on mining sector index in long term. Research results by Muhammadi (2010), Adarmola \& Anthony (2011) shows that the crude oil price had positive influence over stock price index, while the research results from Tjandrasa \& Rosemarie (2016) shows that oil prices had none influence against the stock price index.

The existence of different from these prior research results in producing empirical evidence, it is necessary to do in-depth research about these determinants of mining sector stock index. This research was important considering that this sector closely related to Indonesian macroeconomics and could be one of central issues that interest to examine in domestic and regional macroeconomic forums. This research aims to discover the determinants of mining sector stock index on IDX. The research results were expected to provide correct information to investors regarding the determinants of mining sector stock index so they could help make investment decisions in capital market at IDX. The results of this research were also expected to be useful for policy makers in implementing macroeconomic policies at Indonesian domestic regional and international levels. Besides that, it can also be useful for policy makers in implementing this policy in mining sector. This research would improve financial management knowledge and enhance further research in mining sector.

\section{Literature review}

\subsection{Determinants of Stock Price Index}

The stock price index is movement indicator of stock prices in capital market which has functions as its Trend indicator. The movement from stock price index is source information for investors in making investment decisions to capital market. Bodie (2014) stated that macro-economic factors that affect stock price index, such as inflation, interest rate policy, exchange rates, gross domestic product, social and political conditions. Various factors that could influence this mining sector's shares in capital market are the macro economy and the mining commodity price itself.

\subsection{Inflation}

Sholihin (2010) describes the inflation as an economic condition characterized by rapid increased in prices which has an impact on decreasing purchased power. That condition of rapid price increased had capable to increased production costs due to rising raw material prices which resulted in weakening consumer purchase power. The weakening purchase power of consumers (public) would create difficultness for several companies to sell their products so company sales had decreased which has resulted in decreased on profits and smaller dividends which will have an impact to the decline in stock price performance on stock exchange. For investors, these impact caused by an increase in inflation (high inflation) that it can reduce the level of real income which investors earned from their investment. Sunariyah (2011) stated that inflation that relatively increasing had negative signal for investors.

\subsection{BI Interest Rate}

$\mathrm{BI}$ interest rate is the basic interest rate applied in Indonesia. The movement used as a reference for other interest rates, so if the $\mathrm{BI}$ interest rate rises, it will be followed by an increased in interest rates in other banking industry sector. Sunariyah (2011) states that interest rate is the price of loan which expressed as a percentage of principal per unit of time, where this interest could measure from price of resources used by the debtor to paid off to the creditor. Therefore it could be said that interest rate is the cost of debt or the price that should be paid for lending funds. Ramirez and Khan (1999) stated that there are two types of factors that determine the value of interest rates, which are internal and external factors. Internal factors include national income, money supply and inflation. Meanwhile, external factors are foreign interest rates and the expected rate of change in foreign currency values. According to Lipsey et al. (1997) defined that interest rates are divided into two, namely nominal interest rates and real interest rates. Where the nominal interest rate is the ratio between the amount of money paid back and the amount of money debt. Meanwhile, real interest rates are more emphasis in the ratio of purchase power of money paid back than money lended. 


\subsection{Gross Domestic Product (GDP)}

Gross Domestic Product (GDP) is an economic variable that occupies the most important position from various of macro-economic variables that exist to measure a country's economic performance. GDP is divided into two, namely nominal GDP which describes that added value of goods and services which calculated by prevailing prices each year. Nominal GDP did not reflect real economic welfare, because it does not show the real availability of goods and services needed by consumers, companies, and government also real GDP shows the added value of goods and services calculated based on the prevailing prices in certain year as a basis. Nominal GDP can be used to see economic shifts and structure, while real GDP can be used to determine economic growth from year to year (Mankiw, 2007).

\subsection{Exchange Rate}

The exchange rate is the ratio of the currency value of a country to currency of another country. The exchange rate will change along with the factors of supply and demand. Apart from this, the exchange rate could be influenced by economic conditions. A country's currency that has depreciated quite high would indicated that the country was experienced a weakening economy. This phenomenon was particularly aimed at countries that have a trade balance deficit. Investors will release stocks in capital market due to currency depreciation. This was done by investors to avoid risks arising from weakening domestic currencies.

\subsection{Demand/Supply}

Supply is the ability of producers to produce and offer certain products at certain price for a certain period. Demand is the ability of consumers to buy a certain number of products on certain price and time. The price of a product will be mediated by the amount of supply and demand for that product itself. According to Baye \& Prince (2014), prices were determined by the interaction between market demand and supply. The theory of demand and supply explained current conditions that occur in the market. The market pushes price and quantity to equilibrium level. Economist Alfred Marshall stated that demand and supply are the driving forces behind the movement of the market economy. The form of interaction between price and quantity of goods/services was reflected through demand and supply (Levine et al, 2014). In the ceteris paribus condition, if demand and supply of goods/services increased (decreases), the price of these goods/services will also increase (decrease). Excessive prices cause buyers to seek replacement products. This condition moves until it reaches the equilibrium level when the demand and supply curves intersect at one point as a form of demand and supply balance (Groenewegen, 2007).

\subsection{Coal Price}

Coal is one of the alternative energies which rapid growth, both in terms of production and consumption. This has made the coal industry even more popular, especially after uncontrolled increase in main fuel price such as petroleum. Currently, the largest coal producers in the world are China, USA, India, Australia, South Africa, Russia and Indonesia. Meanwhile, currently the world's largest coal exporters are Indonesia, Australia and Russia. Coal production in China and India are mostly for domestic consumption (Miranti, 2008). There are quite a lot of coal reserves on earth compared to petroleum. This makes coal an alternative to replace the role of petroleum to world industries.

\subsection{Crude Oil Price}

Crude oil is a source of energy that needed and essential for human life. The types of oil which traded in the world include Brent (Brent Blend), WTI (West Texas Intermediate), Dubai Crude, Russian Export Blend. However, the world crude oil benchmark price used Brent and WTI. These fluctuating movements of world crude oil prices were also as an indication that it affects the capital market of a country. Oil used as an ingredient for many industries in world, so it's not surprisingly if there has a lot of demand for oil around the world. The demand is high but the oil resources were decreasing day by day. The vital role of crude oil makes its one of factors that run the world economy. 


\subsection{Research Hypothesis}
H1: Inflation had negative impact toward the mining sector stock index
$\mathrm{H}$ 2: $\mathrm{Bl}$ interest rates had negative influence on the mining sector stock index
H3: Gross Domestic Product had positive influence on the mining sector stock index
H4: Exchange rate had negative influence on the mining sector stock index
H5: Coal supply had positive influence towards the mining sector stock index
H6: Coal demand had positive effect on mining sector stock index
H7: World coal prices had positive impact on mining sector stock index
H8: World crude oil prices had positive influence over mining sector stock index

\section{Methodology of research}

The data used were secondary monthly time series data for period of January 2014 to August 2019 which were published in general. The dependent variable in this research was the mining sector stock index and the independent variable was inflation, $\mathrm{BI}$ interest rate, gross domestic product, exchange rate, coal demand, coal supply, world coal price and world crude oil price.

The analysis method used in this research was Vector Error Correction Model (VECM). This method is a restricted VAR model because the data were not stationary at the level but stationary in first difference and potentially cointegrated. All existing variables were processed in form of natural logarithms. This Vector Autoregressive (VAR) dynamic model was also called an unrestricted VAR (unlimited VAR). intercorrelation relationships from those Variable that could be defined by VAR. These equations from these two variables (bivariate) that had simultaneous causality relationship that could be drawn as its follows (Enders 2014):

$$
\begin{aligned}
& y_{t}=b_{10}-b_{11} z_{t}+\gamma_{11} y_{t-1}+\gamma_{12} z_{t-1}+e_{y t} \\
& z_{t}=b_{20}-b_{21} \gamma_{t}+\gamma_{21} y_{t-1}+\gamma_{12} z_{t-1}+e_{z t}
\end{aligned}
$$

These variables $y$ and $z$ had influenced each other individually on the system. These two equations that can be written in matrix notation as follows.

$$
\begin{aligned}
& {\left[\begin{array}{ll}
1 & b_{11} \\
b_{21} & 1
\end{array}\right]\left[\begin{array}{l}
y_{t} \\
z_{t}
\end{array}\right]=\left[\begin{array}{l}
b_{10} \\
b_{20}
\end{array}\right]+\left[\begin{array}{ll}
\gamma_{11} & \gamma_{12} \\
\gamma_{21} & \gamma_{22}
\end{array}\right]\left[\begin{array}{l}
y_{t-1} \\
z_{t-1}
\end{array}\right]+\left[\begin{array}{l}
e_{y t} \\
e_{z t}
\end{array}\right]} \\
& \begin{array}{llllll}
B & X_{t} & \beta_{0} & \beta_{1} & X_{t-1} & e_{t}
\end{array}
\end{aligned}
$$

The equation has simplified to

$$
B X_{t}=\beta_{0}+\beta_{1} X_{t-1}+e_{t}
$$

If multiplied by B-1 (inverse B), the result becomes a VAR model in the standard form or it called as reduced form.

$$
X_{t}=A_{0}+A_{1} X_{t-1}+\varepsilon_{t}
$$

VAR model used in this research was presented in the following equation belows (Enders 2014):

$$
Y_{t}=A_{0}+A_{1} Y_{t-1}+\vartheta_{t}
$$

Through this equation, it could be explained that there had reciprocal dynamic relationship between variables. The impulse responds to shocks that occur in certain variables to other variables. The contribution between variables could be measured through this model. The problem in several events is because time series variable is not stationary at the level, but stationary in difference. If the variables were analyzed for potential cointegration, then this condition the VAR model cannot be applied as a form of unrestricted VAR (infinite VAR). So it is necessary to apply the restricted VAR model. This model is called as Vector Error Correction Model (VECM). This model could explain the short-term and long-term cointegration relationships between variables. According to Firdaus (2011), VECM model could be written in this following equation.

$$
\Delta y_{t}=\mu_{0 x}+\mu_{1 x} t+\Pi_{x} y_{t-1}+\sum_{i=1}^{k-1} \Gamma_{i x} \Delta y_{t-1}+\varepsilon_{t}, \quad t=1,2, \ldots
$$


The stages from this analysis method in this research were as in follows: (1) Data Stationarity Test (unit root test), examined at this stage by Augmented Dickey Fuller (ADF). If the variable did not have a unit root, it means that stationary at that level, so VAR is used; (2) VAR stability analysis; (3) optimal lag length; (4) if the variable has a unit root, it means that variable is not stationary at the level or the variable is stationary at the first difference, so it is necessary to carry out the Johansen cointegration test. If there has cointegration then use VECM. If there is no cointegration then further analysis is required; (5) Impulse Response Function (IRF) analysis; (6) analysis of Forecasting Error Variance Decomposition (FEVD).

\section{Results and discussions}

\subsection{All Variables were Not Stationary in Level But Stationary in First Difference}

Based on the results from this unit root test by Augmented Dickey Fuller (ADF) in table 1 it shows that all variables were not stationary at the level but stationary at the first difference level. This means that there had an imbalance (disequilibrium) between dependent variable and independent variable, so it is necessary to do a cointegration test to see the long-term equilibrium relationship.

Table 1. Augmented Dickey Fuller (ADF) Unit Root Test Results

\begin{tabular}{ccccc}
\hline \multirow{2}{*}{ Variable } & \multicolumn{2}{c}{ Level } & \multicolumn{2}{c}{ First Difference } \\
\cline { 2 - 5 } & ADF t-Statistic & p-value & ADF t-Statistic & p-value \\
\hline ISSP & -0.957644 & 0,7635 & -6.810343 & $0.0000^{*}$ \\
INF & -2.108619 & 0.2420 & -6.449854 & $0.0000^{*}$ \\
SBI & -1.273877 & 0.6369 & -5.665775 & $0.0000^{*}$ \\
PDB & 0.025364 & 0.9567 & -8.154913 & $0.0000^{*}$ \\
USD & -1.263720 & 0.6416 & -7.022112 & $0.0000^{*}$ \\
DSP & -1.716934 & 0.4175 & -7.268643 & $0.0000^{*}$ \\
SSP & -2.502507 & 0.1194 & -10.88916 & $0.0000^{*}$ \\
COAL & -1.508477 & 0.5232 & -5.827086 & $0.0000^{*}$ \\
WTI & -2.099971 & 0.2454 & -6.602427 & $0.0000^{*}$ \\
\hline
\end{tabular}

*) Stationer on Prob. 5\%

Information: ISSP is the stock index of mining sector, INF is inflation, SBI is the BI interest rate, GDP is Gross Domestic Product, USD is the exchange rate of US Dollar to Rupiah, DSP is coal demand, SSP is coal supply, COAL is the world coal price, WTI is world crude oil prices

\subsection{VAR Stability is at lag 4 and optimal lag length is lag 1}

Based on VAR stability test result, the maximum lag length from this VAR model is lag 4 . This means that IRF data and FEVD were considered valid. The results from optimal lag length test based on criteria of Likelihood Ratio (LR), Final Prediction Error (FPE), Akaike Information Criterion (AIC), Schwarz Information Criterion (SC), and Hannan-Quinn Criterion (HQ) were presented in Table 2. The purpose in conducting this optimal lag test was to eliminate autocorrelation problem in VAR system. The optimal lag length in this research was lag length 1.

Table 2. Optimal Lag Length Test Results

\begin{tabular}{ccccccc}
\hline Lag & LogL & LR & FPE & AIC & SC & HQ \\
\hline 0 & 496.1202 & NA & $1.98 \mathrm{e}-18$ & -15.22251 & -14.91891 & -15.10291 \\
1 & 1032.577 & 905.2711 & $1.16 \mathrm{e}-24^{*}$ & -29.45554 & $-26.41961^{*}$ & $-28.25953^{*}$ \\
2 & 1122.614 & $126.6141^{*}$ & $1.33 \mathrm{e}-24$ & -29.73793 & -23.96967 & -27.46552 \\
3 & 1208.850 & 97.01622 & $1.48 \mathrm{e}-24$ & -29.90158 & -21.40098 & -26.55276 \\
4 & 1318.001 & 92.09578 & $1.50 \mathrm{e}-24$ & $-30.78128^{*}$ & -19.54834 & -26.35606 \\
\hline
\end{tabular}

* indicates lag order selected by the criterion

LR: sequential modified LR test statistic (each test at $5 \%$ level)

FPE: Final prediction error

AIC: Akaike information criterion

SC: Schwarz information criterion

HQ: Hannan-Quinn information criterion 


\subsection{There are 5 cointegration equations between variables}

These cointegration test method used Johansen's Cointegration test. Johansen cointegration was examined those criteria based on trace statistics. If the trace statistic value was greater than critical value 0.05 , it means that there had cointegration so that VAR model could be developed into VECM. Table 3 had explained that there are five cointegration equations at 0.05 level and trace statistic value was greater than critical value 0.05 so it could be continued on VECM stage. The cointegration test was indicated that there had equilibrium relationship in the long run between variables or in other words all variables had the same direction of movement in the long run.

Table 3. Johansen Cointegration Test Results

\begin{tabular}{ccccc}
\hline $\begin{array}{c}\text { Hypothesized } \\
\text { No. of CE(s) }\end{array}$ & Eigenvalue & $\begin{array}{c}\text { Trace } \\
\text { Statistic }\end{array}$ & $\begin{array}{c}\mathbf{0 . 0 5} \\
\text { Critical Value }\end{array}$ & Prob.** \\
\hline None * & 0.694448 & 287.3319 & 197.3709 & 0.0000 \\
At most 1 & 0.641872 & 209.0799 & 159.5297 & 0.0000 \\
At most 2 & 0.437097 & 141.3069 & 125.6154 & 0.0100 \\
At most 3 & 0.397566 & 103.3801 & 95.75366 & 0.0254 \\
At most 4 & 0.356833 & 69.93291 & 69.81889 & 0.0370 \\
At most 5 & 0.194299 & 40.80371 & 47.85613 & 0.0388 \\
At most 6 & 0.159466 & 26.54487 & 29.79707 & 0.0270 \\
At most 7 & 0.117902 & 15.07951 & 15.49471 & 0.0256 \\
At most 8 & 0.097895 & 6.799639 & 3.841466 & 0.0103 \\
None & 0.694448 & 287.3319 & 197.3709 & 0.0000 \\
\hline
\end{tabular}

Trace test indicates 5 cointegrating eqn(s) at the 0.05 level

* denotes rejection of the hypothesis at the 0.05 level

**MacKinnon-Haug-Michelis (1999) p-values

\subsection{Impulse Responsed Function Analysis (IRF)}

Impulse responsed function (IRF) is a short and long term simulation from respond of variable due to shocks that occur in other variables. The respond that occurs in short term usually quite significant and tends to change and those respond in long term tends to be consistent and stable. The IRF analysis method used to determine these response from mining sector stock index due to shocks from independent variables such as inflation, interest rates, Indonesian GDP, exchange rates, coal demand, coal supply, coal prices and crude oil prices. The horizontal axis shows the period (in months) of response given due to shocks occurring in independent variable. Meanwhile, the vertical axis shows that the standard deviation value which measures the amount of response that will be given, in case of shock to independent variable. IRF line which above horizontal axis was indicated that shocks had positive influence and does it Conversely, if the IRF line is below the horizontal axis, it was indicated that shocks had negative effect. The results from IRF analysis based on VECM were presented in Figure 3 and Figure 4.

Figure 3 shows that shock that occured in one standard deviation to inflation will be responded positively by the mining sector stock index in the long run. This means that if inflation increases, it will be followed by increase in mining sector stock index. This influence can be responded by the mining sector stock index up to twenty-second period. Shocks in $\mathrm{BI}$ interest rate of one standard deviation will be responded negatively by mining sector stock index in the long run. This means that if the interest rate increase, it will be followed by decrease in the mining sector stock index. This influence could be responded by the mining sector stock index up to twenty-first period.

Shocks on Gross Domestic Product of one standard deviation had negative response to mining sector stock index in the long run. This means that if Gross Domestic Product increases, it will be followed by a decrease in mining sector stock index. This influence could be responded by the mining sector stock index up to twenty-second period. The shock of US Dollar exchange rate against Rupiah of one standard deviation was responded negatively by the mining sector stock index in the long run. This means that if the Rupiah weakens, the USD is strengthening, it will be followed by the declined in mining sector stock index. This influence could be responded by mining sector stock index up to seventeen period. 

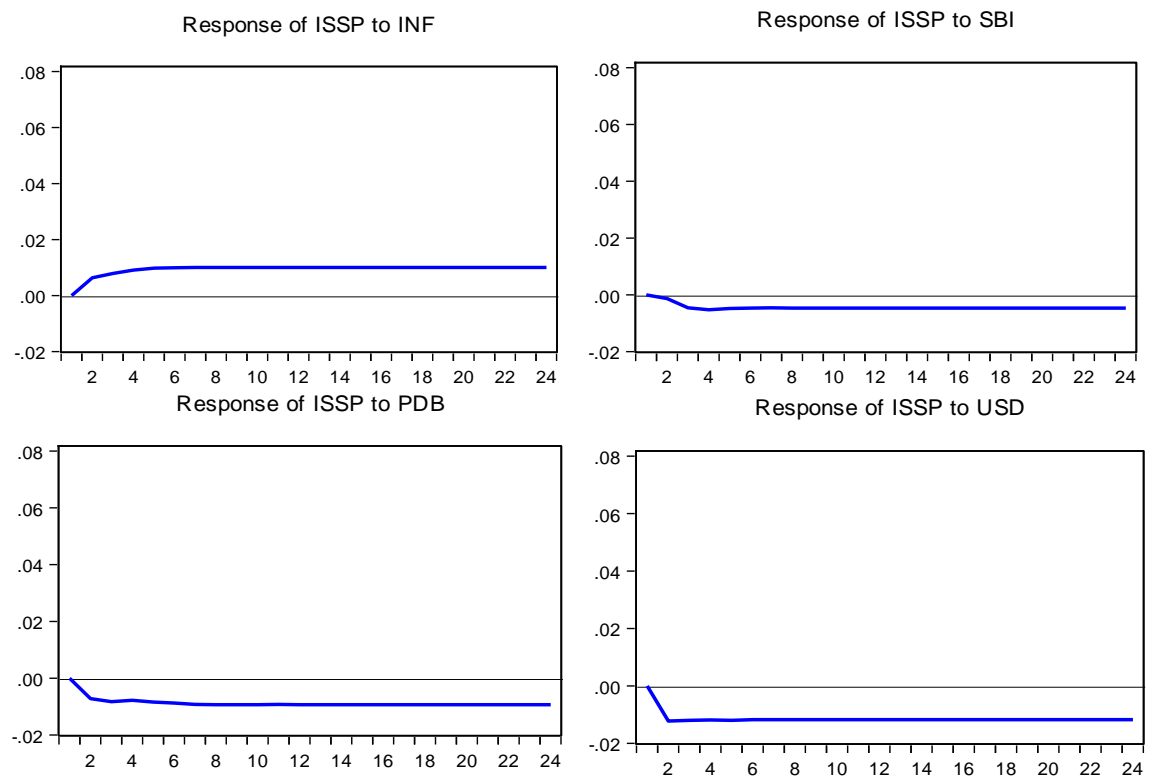

Figure 3. The results of the Impulse Response Function analysis of INF, SBI, GDP, USD

Figure 4 shows that coal supply shocked for one standard deviation, so the mining sector stock index will reacted positively in the long run. This means that if coal supply increased, it will be followed by increasing in the mining sector stock index. This influence could be responded by mining sector stock index up to the twenty-first period. Coal demand shocks of one standard deviation had positive respond to mining sector stock index in the long run. This means that if coal demand increase, it will be followed by an increase in mining sector stock index. This influence could be responded to by the mining sector stock index up to twenty-second period.

Shocks of one standard deviation in coal prices had positive response to mining sector stock index in the long run. A positive response means that if the price of coal increased, it will be followed by an increase in the mining sector stock index. This influence could be responded to mining sector stock index up to eighteen period. A crude oil price shock of one standard deviation has positive respond in mining sector stock index in the long run. This means that if the price of crude oil increased, it will be followed increase in the mining sector stock index. This influence can be responded to by the mining sector stock index up to period twenty.

Response of ISSP to DSP
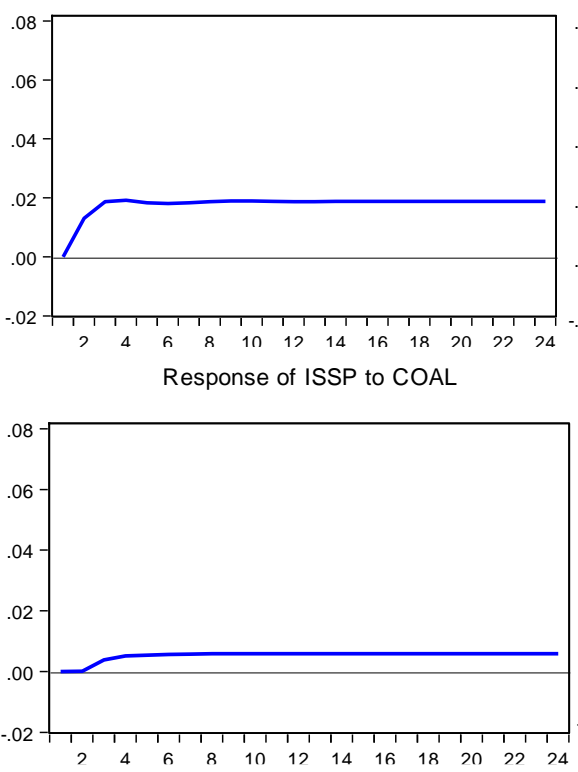

Response of ISSP to SSP
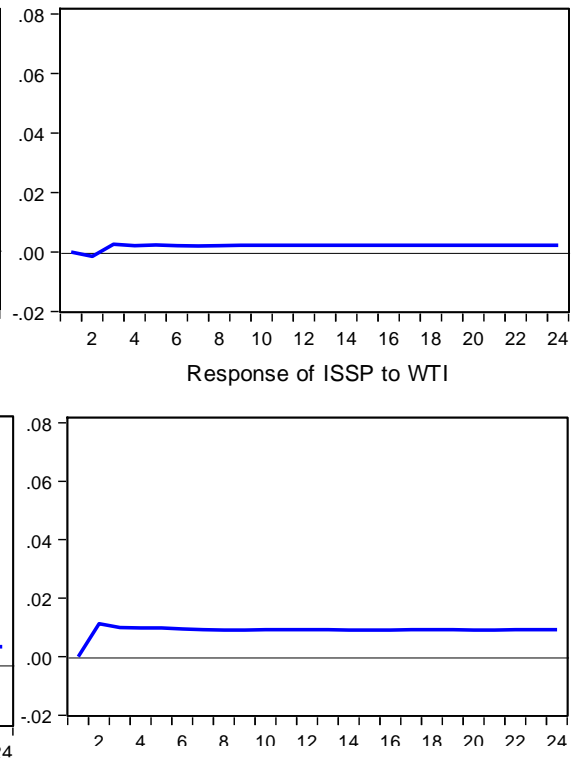

Figure 4. The results from Impulse Respond Function analysis to CNS, DSP, COAL, WTI 


\subsection{Forecasting Error Variance Decomposition (FEVD) Analysis}

Forecasting Error Variance Decomposition (FEVD) analysis aims to predicted which independent variable contributes to the most in explaining changes in dependent variable in the short and long term. FEVD analysis in this research was projected over 24 periods (months). The dominant contribution to changes in mining sector stock index on long term (twenty-fourth period) from these FEVD analysis result as its follows: the mining sector stock index itself was 65.53 percent, Gross Domestic Product (GDP) was 9.97 percent, $\mathrm{BI}$ interest (SBI) was 9.71 percent, exchange rate (USD) was 7.05 percent, coal supply (SSP) was 4.82 percent, world crude oil price (WTI) was 1.39 percent, coal demand (DSP) ) by 0.74 percent, inflation (INF) by 0.50 percent and world coal price (COAL) by 0.27 percent. The large contribution on mining sector stock index meaning that movement on mining sector stock index was influenced by financial performance from mining companies itself and which will affect their share prices.

\section{Conclusions}

Shocks which occurred in Inflation variable (INF), coal supply (SSP), coal demand (DSP), coal prices (COAL) and world crude oil prices (WTI) were responded positively by mining sector stock index while shocks which occurred in BI interest rate variable (SBI), Gross Domestic Product (GDP) and exchange rate (USD) was responded negatively by mining sector stock index. It means that all variables are determinant of mining sector stock price index at IDX.

Mining sector stock index was strongly influenced by mining sector stock index itself, which means that movement from mining sector stock index was influenced by financial performance of mining companies which will impact to their stocks prices. In the long term (twenty-fourth period) those independent variable that contributed dominantly to changes in mining sector stock index was coal demand (DSP) around 4.60 percent. High demand for coal will driving coal companies to increase their production followed by an increase in jointed profits which will have positive impact on company performance so as to attract investors' attention to invest which would increase stock prices.

The findings of the current study are important for investors as information about the mining sector stock index at IDX. Investors must consider macro-economic factors and mining commodity prices in making decisions. This is important because shocks occur in all the variables that will affect the movement of the mining sector stock index in the long term. This research had useful for regulators in making macroeconomic policies in Indonesia while maintaining monetary stability, especially the exchange rate (exchange rate), inflation, GDP, interest rates. This is important because it has an influence on the movement of the mining sector stock index on the IDX. In addition, this research can also contribute to the academic field, which can be a reference for further research regarding the determinants of the mining sector stock index in the event of a change in policy or a change in new market conditions.

\section{References}

1. Adaramola, A. O. (2011). The Impact of Macroeconomic Indicators on Stock Prices in Nigeria. International Knowlage Sharing Platform, Vol 1(2), DOI: https://doi.org/10.7176/DCS.

2. Anisa, I., \& Ari, D. (2018). Pengaruh Ekonomi Makro Dan Harga Komoditas Tambang Dunia Terhadap Indeks Harga Saham Sektor Pertambangan Di Indonesia (The Effect Economic Macro and World Mining Commodity on the Mining Sector Stock Price Index). Jurnal Administration Bisnis (JAB) Vol 56(1), 197-206.

3. Amadasu, D. E. (2012). Interest Rate, Inflation Rate and Exchange Rate Influence on the Nigerian Market Index. An International of Arts and Humanities Bahir Dar Ethiopia, Vol 1(3)., 357-366.

4. Baye, M. R., \& Prince, J. T. (2014). Managerial Economics and Business Strategy. Ed. ke-8. New York: McGraw Hill.

5. Bodie, Z., Kane, A., \& Marcus, A. J. (2014). Investment Tenth Edition. United States of America: McGraw-Hill.

6. Cong, R. G., Wei, Y., M., Jiao, J. L., \& Fan, Y. (2008). Relationships between oil price shocks and stock market: An empirical analysis from China. Energy Policy Vol. 36(9), 3544-3553. 
7. Enders, W. (2014). Applied Econometric Time Series. Ed. ke-4. New Jersey (US): John Wiley and Sons.

8. Fardiansyah, A., Victor, S., \& Pardomuan S. (2018). Determinan indeks sektor pertambangan di BEI periode 2012 - 2017 (The Determinant of the Mining Sector index in the IDX period 2012 - 2017). Seminar Nasional Cendekiawan ke 4.

9. Firdaus, M. (2011). Aplikasi Ekonometrika Untuk Data Panel dan Time Series. Bogor. PT. Penerbit IPB Press.

10. Gogineni, S. (2008). The Stock Market Reaction to Oil Price Changes. SSRN.

11. Hosseini, S. M., Ahmad, Z., \& Lay, Y. (2011). The Role of Macroeconomic Variables on Stock Market Index in China and India. International Journal economic and Finance Vol. 3(6), 233-243, doi:10.5539/ijef.v3n6p233.

12. Inglis, J. (2014). Capital Market and Economic Growth: Long Term Trends and Policy Challenges. AIMA Working Paper.

13. Levine, S., Taylor, G., Arthur, D., \& Tolleth, M. (2014). Understanding Crude Oil and Product Markets. Washington (US): American Petroleum Institute.

14. Lipsey, Richard, G., Paul, N. C., and Christopher, T. S. R. (1997). Macroeconomics, Ninth Canadian Edition. The Addison-Wesley Educational Publishers.

15. Mankiw, N. G. (2007). Makroekonomi. Edisi Keenam. Jakarta: Penerbit Erlangga.

16. Miranti, E. (2008). Prospek Industri Batubara di Indonesia (Prospects of the Coal Industry in Indonesia). Economic Review No. 124.

17. Movahedizabeh, H., Anuar, M. D. N., Meisam, A. K., Mehdi, K., Navid, S. S., \& Ehsan, B. (2014). The impact of macroeconomics factor on Tehran Stock Exchange Index during unjust economic and oil sanctions from January 2006 to December 2012. Recent Advances in Economics, Management and Marketing, 112-121.

Muhammadi, N. E. (2010). Pengaruh Makro Ekonomi Terhadap Indeks Harga Saham Sektoral di Bursa Efek Indonesia Periode 2000-2008 (Macroeconomic Effects on the Sectoral Stock Price Index on the Indonesia Stock Exchange). Tesis, Program Magister Perencanaan dan Kebijakan Publik Universitas Indonesia, Jakarta. From lib.ui.ac.id.

18. Prowanta, E., Moeljadi., Sumiati., \& Ratnawati, K. (2017). The Impact of Macro Economy on Stock Price Index: An Empirical Study of Five ASEAN Countries. Global Journal of Business and Social Science Review. Review 5(2), $40-45$.

19. Ramirez, Miguel, D., \& Khan, S. (1999). Cointegration Analysis of PPP. USA: Trinity College.

20. Sholihin, A. (2010). Buku Pintar Ekonomi Syariah. Jakarta (ID). Gramedia Pustaka Utama.

21. Sunariyah. (2011). PengantarPengetahuan Pasar Modal, Yogyakarta: UPP STIM YKPN.

22. Tandelilin, E. (2010). Portofolio dan Investasi: Teori dan Aplikasi (Portfolios and Investments: Theory and Application). Edisi Pertama. Yogyakarta: Kanisius.

23. Tjandrasa, B. B., \& Rosemarie, S. (2016). Effect of World Gold Price, Crude Oil Price and Interest Rate to Jakarta Composite Index. International Journal of Education and Research, Vol 4 No. (7) , 215-222.

24. Wahyudi, S., Hersugondo., Rio, D. L., \& Rudy. (2017). Macroeconomic Fundamental and Stock Price Index in Southeast Asia Countries: A Comparative Study. International Journal of Economics and Financial Issues, Vol 7(2), 182-187.

25. Zurdona, E. W. P. (2018). Analisis Determinasi Harga Komoditas Pertambangan Terhadap Indeks Mining di IHSG (Indeks Harga Saham Gabungan) Periode Januari 2016 - Agustus 2017. Ilmu Ekonomi Fakultas Ekonomi dan Bisnis. Universitas Muhammadiyah Yogyakarta. From repository.umy.ac.id 